\title{
Attitude of university students on online teaching under corona virus pandemic situation in Pakistan
}

\author{
Bareera Saeed $^{* 1-2} \mid$ Asmat Ullah $^{3} \mid$ Muhammad Ali Khan ${ }^{4}$
}

1. Department of Health Professional Technologies, University of Lahore, Lahore, Pakistan.

2. Department of Psychology, University of Karachi, Karachi, Pakistan.

3. National Institute of Pakistan Studies, Quaid-e-Azam University, Islamabad, Pakistan.

4. Department of Psychology, Ohio Northern University, Ada, Ohio, United States.

* Correspondence Emails: bareera.saeed@dpht.uol.edu.pk | bareerasaeedwarraich@gmail.com

\begin{abstract}
The COVID-19 has resulted in schools, colleges and universities shut all across the world. As a result; education has changed dramatically, with the distinctive rise of e-learning, whereby teaching is undertaken remotely and on digital platforms. This research study examines the attitudes of university students towards online teaching under corona virus pandemic situation in Pakistan. A cross sectional study design was used on 400 (Male=195, Female=205) university students. A convenient sampling technique was used to draw the sample from different universities in the province of Punjab, Pakistan. An online survey was conducted to collect the data. Descriptive statistics were calculated out to measure the distribution of attitude of study participants. Frequency and percentages were estimated to assess the attitude towards online mode of learning, and opinion on educational decisions, and problems related to study due to lockdown. All analyses were performed using the SPSS-V20. The results of study highlighted that a large majority of student (83.9 percent) preferred face-to-face classroom teaching method. This study concluded that in Pakistan, despite picking up gigantic ubiquity nowadays, virtual education has still not been grasped by students. Students are still more in the favour of face-to-face classroom teaching.
\end{abstract}

Article History

Received:

January 3, 2021

Last Revised:

March 27, 2021

Accepted:

March 28, 2021

Published:

April 12, 2021

Keywords: COVID-19, education, learning approach, students learning approach, classroom, online classes, traditional teaching, online teaching, e-learning.

How to Cite: Saeed, B., Ullah, A. \& Khan, M. A. (2021). Attitude of university students on online teaching under corona virus pandemic situation in Pakistan. Liberal Arts \& Social Sciences International Journal (LASSIJ), 5(1), 28-40. https://doi.org/10.47264/idea.lassij/5.1.3

Publisher's Note: IDEA PUBLISHERS (IDEA Journals Group) stands neutral with regard to the jurisdictional claims in the published maps and the institutional affiliations.

Copyright: ( 2021 The Author(s), published by IDEA PUBLISHERS (IDEA Journals Group). This is an Open Access article published under the Creative Commons Attribution-NonCommercial 4.0 International License (http://creativecommons.org/licenses/by-nc/4.0/) 


\section{Introduction}

The COVID-19 has resulted in schools, colleges and universities shut all across the world. Globally, over 1.2 billion children are out of the classrooms. As a result; education has changed dramatically, with the distinctive rise of e-learning, whereby teaching is undertaken remotely and on digital platforms. The COVID-19 has casted a huge impact on education systems around the world. It caused many schools, colleges and universities shut worldwide (Burgess \& Sievertsen, 2020). Around the world, it is estimated that more than 1.2 billion kids are out of the classrooms owing to novel pandemic situation. Resultantly, countries adopted online teaching systems whereby teaching material is delivered through online platforms (Burgess \& Sievertsen, 2020). Studies depict that, it takes less time in delivery of teaching material (Zeglen $\&$ Rosendale, 2018). While many countries of the world are undergoing different levels of COVID-19 infections, which affected about 1.2 billion children in 186 countries access to educational institutions (Viner et al., 2020). In Denmark, educational institutions were closed in March, currently, as of September, 2020 school kids under 12 are again back in schools, however, in South Korea students are learning through online systems (Crawford et al., 2020; Stage et al., 2020). In Pakistan, educational institutes were closed from 1st week of March and students are attending their class through interment from their homes (Nicola et al., 2020). Many observers are pondering over the question whether abrupt shift on this system of online education system in large number of countries will continue unabated in post pandemic period or it will vanish (Adnan \& Anwar, 2020).

Even in the pre COVID-19 world, education technology witnessed a huge sum of investment approximately US\$19 billion in last year and the projections showed that it would reach $\$ 350$ billion in next five years. Multiple education centric applications, virtual mentoring, conferences through video links, or variant programs of learning, there has been an upward trajectory in utilization of all such options after the onset of COVID-19 (Hoq, 2020). Online learning is seen as less effective in Pakistan and in the third world countries as compared to the developed countries. One of reason regarding Pakistan can be that here most of the activities regarding education as well as administrations are handled manually. Another reason can be that people are not much familiar with the usage of technology in Pakistan. There are also many other issues like internet availability and speed issue, lack of access to necessary technology, issues of psychological adjustment to accept the new model of learning (Salam et al., 2017).

Online learning can be more effective and all positive factors associated with this type of learning can be useful if educational institutions try to develop a reasonable system for it. To develop the proper system for new model of learning i.e., online learning there is a great need to change or modify the curriculum in the new context. There is also a need to introduce the new or modified teaching method which goes effectively parallel with new model of learning. Not only curriculum should be revised and new teaching methods are introduced, but also educational scientists should redefine the objective and outcomes of new model of online learning (Zhang et al., 2020). Another major hindrance in the way of effectiveness of online learning is student teacher interaction. Students and teachers both are not used to and satisfied with e-communication. An adaptation to this new system is not being warmly welcomed. Instructors and students are facing communication gap and badly missing the conventional classroom system. There seems an attachment to the traditional system of learning whereby instructor and the students are physically present. Moreover, educational institutions and traditional classrooms provide room for satisfactory communication of knowledge, ideas and socialization (Pace et al., 2020). 
However, despite all these problems it remains a fact that online learning is the only way, which helps to carry on with learning process in this pandemic situation. This new model of learning really rescues the educators in this hard time of pandemic. In the online learning there are many online available tools which are used by the educators to make it effective and efficient learning method like audio, video recoded lectures, zoom meetings with the students. To make the online learning more effective and efficient, educational scientists are doing numerous researches and educational institutes are investing more funds to develop a technical setup for online learning (Dhawan, 2020). However, there is a need to understand the attitudes of university students on online learning. The aim of this research study is to evaluate the attitude of university students towards online learning under corona virus pandemic situation in Pakistan. This study revolves around the research question that was: What are the attitudes of university students towards online teaching in coronavirus pandemic situation. Moreover, this research highlights the basic and important factors contributed to build the attitude of university students of Pakistan towards online teaching in pandemic situation. Many students (47.8 percent) were motivated to share experience of their online classes qualitatively to better express their unique issues and challenges. This academic exercise depicted that despite the face that online learning is popular in Pakistan; however, many students have not accepted it wholeheartedly.

\section{Literature review}

Over the past few years, there has been a tremendous increase in the enrolment in online courses in United States. For example, in 2008, there has been around 13 percent increase than the previous academic year in online enrolment (Allen \& Seaman, 2008). But, due to pandemic situation globally rate of online classes became significantly high (Crawford et al., 2020). Owing to this high demand well known online platforms like BYJU's, educational technology firm since 2011, opened free access to their platforms (Zeglen \& Rosendale, 2018). This firm witnessed 200 percent increase in its users. Moreover, unforeseen advent of Covid-19 provided a foundation for a massive Tencent Education program based on online learning concept. Amidst lockdown there has been a massive surge in the domain of online education system in China whereby millions of students continued their studies unabated despite complete closure of educational institutions to avoid the spread of Covid-19. It engendered a major trend in history of the education whereby billions of the students have been using online platforms for educational purposes. Roughly 730,000 , or $81 \%$ of K-12 students, attended their classes online through Tencent the Chinese city of Wuhan (Kumar, 2020).

However, many people opine that abrupt shift on the novel online system coupled with the issues of proper preparedness, poor training and insufficient bandwidth will eventuate in poor user experience, which is unfriendly to sustained growth of this novel system. On the other hand, many people consider that new model of education system i.e., 'Hybrid' will appear with promising advantages. It is also being assumed that information technology will incorporate increase in education with time, resultantly, online education will become essential part of the education (Aslam et al., 2020; Ni, 2013).

Online learning can be more effective in various forms for the people who are devoid of right technology as shown by research (Nguyen, 2015). Technological revolution has facilitated distant educated significantly. Rapid developments in technology have made distance education easy (McBrien et al., 2009). Online learning coupled with many other terms like web-based learning, blended model of learning etc., use a computer and a network that can be 
used for learning purposes from anywhere in the world (Cojocariu \& Boghian, 2014). It equips learning process with innovation and flexibility. It is also student friendly. Through online learning system students can access their classes from anywhere in the world using modern gadgets like cell phones, tablets and laptops connected with the internet. In this process students and teachers have a real time interaction. It also facilitates live feedback, and learning material can be accessed even after the classes, which, on the other hand, is not available in physical class-based learning method. Live lectures can be seen repeatedly and lectures can be attended from anywhere on mobile devices. Access to educational material is not time bound. A student can access learning material according to his free time (Singh \& Thurman, 2019).

In addition, research also shows that student's retention is higher in online system, approximately 25-60 percent than traditional classrooms this is because students need less time approximately 40-60 percent in online teaching delivery systems. Availability of more time enables them to reread and bring information back for learning whenever and wherever they need. They are also able to skip already learned material and move forward. Hence, it makes time more manageable and productive. It is beyond the realm of doubt that pandemic casted huge impact on educational system around the world (Pace et al., 2020). Many scholars hold the opinion that traditional educational system had been losing its relevance (Kumar, 2020). Traditional educational system is losing its relevance in modern era because of its traditional approach on academic skills which is unfriendly to critical thinking and adaptability in future (McDonnell, 2019).

Question arises whether this novel online learning system is a panacea to ills of traditional educational system and the shift from traditional to modern system is safe, effective, and adaptable? Many people believe that sudden transition with loopholes may cause damage to aforementioned goal. On the other hand, there exists a strong opinion that online learning should be a new normal in education domain because of its advantages (James et al., 2008). Amidst this global debate on online education system whereby its effectiveness in learning, sustainability, growth, lack of uniform access to digital gadgets to reach online education, its potential to make traditional education system obsolete, and issues related to internet access, current study is an attempt to analyze these variables in online education system of Pakistan in Covid-19 pandemic situation in Pakistan.

\subsection{Theoretical framework}

This study is based on the concept of Bloom's Taxonomy that was proposed by the Benjamin Bloom for eLearning courses. Benjamin Bloom identified the tree domains in Bloom taxonomy. 1- Cognitive 2- Affective 3- Psychomotor. Cognitive domain is consisted of six levels (knowledge, comprehension, application, analysis, synthesis, evaluation) and responsible for the development of intellectual skills. Affective domains are divided into five levels (Receiving, responding, value, organizing and characterizing) and focuses on attitude, feeling and emotions of learner (Adams, 2015).

This study is focusing on the affective domain of the Bloom's Taxonomy, which is related, with the attitude of the learner. Affective domain contains attitude, emotions, and feelings of learner. This comprises the ways of emotionally dealing with internal and external phenomenon i.e., motivations, enthusiasm, and values. Affective domain of Taxonomy theory is divided into five levels of hierarchy (Adams, 2015). In this study items used in questionnaire were based on these five levels of affective domain. These steps are explained below through figure- 1 . 


\section{Characterization}

- To build synthesis

\section{Organization}

- Internalization/externalization of phenomenon

\section{Value}

- To build Psychological and cognative association with phenomemon

\section{Responding}

- Efficent participation of learner

\section{Receving}

- Focused Attention, Awareness and willingness to listen

Figure 1: Hierarchy of Affective Domain of Taxonomy Theory

\section{Research methodology}

This is a quantitative study for which data has been collected through structured questionnaire.

\subsection{Sample}

A cross sectional study design was used on 400 (Male $=195$, Female $=205$ ) university students of age 17 to 30 years (Mean $=1.3775, \mathrm{SD}=0.48537$ ) to measure the attitude of students towards online learning. A convenient sampling technique was used to draw the sample of students from different universities in the province of Punjab, Pakistan. Undergraduate and postgraduate students of Sciences, Social Sciences and Humanities were included in the study and have been attending their online classes.

\subsection{Measurement}

A structured close-ended questionnaire, based on thirty-five items related to psychological effects of online classes, technical issues, quality of education in online learning, student's perspective of online classes, was used to assess the attitude of university students towards online teaching under corona virus pandemic situation in Pakistan. Questionnaire was developed through the literature and expert's opinion. Apposite amendments were made in questionnaire based on expert's remarks and suggestions.

\subsection{Procedure}

Data has been collected from the university students through an online survey. An online structured questionnaire link was generated through Google Form that link was sent to different university students all over the Punjab through Email, Facebook, and WhatsApp. A consent form was signed, which was attached with questionnaire and the link, was taken from all the participants of this study. 


\subsection{Limitations}

Non-random selection of samples puts limitations on generality of this study and university participants were included only from Punjab province.

\section{Analysis and discussion}

Descriptive statistics was used to measure the age of the participants. Percentage and Frequency were used to assess the attitude of university students towards online education. Data was entered and analyzed through the Statistical Package for Social Science SPSS-V20. Before moving towards statistical analysis, table 1 shows demographic information of sample. Table-1 shows that 400 (Male=195, Female=205) university students of age 17 to 30 years (Mean $=1.3775$, SD $=0.48537$ ) participated in the study. Female students comprised 51.3percent while 48.8 percent were male student in the study. Students from sciences were 45.75 while 34.5 percent were from social sciences and 19.8 percent were from Art and humanities. Undergraduate students represented $61.3 \%(\mathrm{n}=245)$ of study sample, whereas $38.8 \%(\mathrm{n}=155)$ were postgraduate students. Students studying in private universities were 45.8 while 34.5 were studding in public sector universities. Students in semi-government universities were 19.8 percent. Students attending online classes through Zoom were 50.5 percent. Furthermore, students attending online classes through WhatsApp were 25.8 percent. Students who used recorded lectures were 23 percent. Students who attended online class more than three to six months were 57.5 percent. In addition, 49.8 percent students got 60 to 79 percent marks. Previous semester GPA of 59.5 percent students were 3.00 to above.

In majority of the surveys the university students have reservations about online/digital learning. Issue of standard internet connectivity which ensures smooth connectivity and speed is another factor that caused problem to the students of higher education in Pakistan. Abrupt shift from traditional classroom-based system to online learning has also resulted in a completely different learning experience for the students (Maddux et al., 2007). Online education system has many challenges to overcome for its sustained growth. Many students have issues of internet availability to partake in online classes. This gap is not uniform and varies in countries and regions of the world. According to Organization for Economic Cooperation and Development (OECD) 95 percent of students in Switzerland, Australia, and Norway have a computer to utilize for their studies, but as it were $34 \%$ in Indonesia do possess computers for the same reason. Likewise, there is also a stark gap of computer accessibility in United States between privileged and disadvantaged. All 15 years from a sound background do have computers; on the other hand, nearly 25 percent from disadvantaged backgrounds do not have computers for study (Bulman \& Fairlie, 2016).

Around the world, several governments have been trying to assure the provision of electronic gadgets to students in need to enable them to have a uniform access to educational opportunity, such as in New South Wales, Australia, but many observers of online education system are apprehensive that pandemic situation will enlarge the gap between who have an access to digital gadgets and those who have not (Flack et al., 2020). University students hold a divided response on online classes in pandemic situation in Pakistan. Majority of the students were not attending online classes regularly and actively. Students were not at all satisfied with learning through online classes owing to multiple reasons discussed hereinafter. Students were also feeling difficulty to concentrate during online class. Poor Internet connectivity and limited access to technology is a basic hurdle in online classes for many students in Pakistan. Recent 
researches have also shown that students are facing problems due to limited internet connectivity and low speed (Adnan \& Anwar, 2020).

Table-1: Demographic characteristics of university students attending online classes $(\mathrm{N}=400)$

\begin{tabular}{|c|c|c|c|}
\hline Description & & Frequency $(\mathrm{n})$ & Percentage $(\%)$ \\
\hline \multirow{2}{*}{ Age } & 17-21 years & 249 & 62.3 \\
\hline & 22 year and above & 151 & 37.8 \\
\hline \multirow{2}{*}{ Gender } & Female & 205 & 51.3 \\
\hline & Male & 195 & 48.8 \\
\hline \multirow{3}{*}{ Felid of Study } & Sciences & 183 & 45.75 \\
\hline & Social Sciences & 138 & 34.5 \\
\hline & Art and Humanities & 79 & 19.8 \\
\hline \multirow{2}{*}{ Level of study } & Undergraduate & 245 & 61.3 \\
\hline & Post graduate & 155 & 38.8 \\
\hline \multirow{3}{*}{ Previous Semester GPA } & 3.00 to above & 238 & 59.5 \\
\hline & 2.50 to 3.00 & 124 & 31.0 \\
\hline & 2.00 to 2.50 & 38 & 9.5 \\
\hline \multirow{3}{*}{ University in which studying } & Public & 138 & 34.5 \\
\hline & Private & 183 & 45.8 \\
\hline & Semi government & 79 & 19.8 \\
\hline \multirow{3}{*}{ Attending Online Classes through } & Zoom & 202 & 50.5 \\
\hline & WhatsApp & 103 & 25.8 \\
\hline & Recorded Lecture & 95 & 23.8 \\
\hline \multirow{3}{*}{ Attending online classes Since } & Six months and above & 52 & 13.0 \\
\hline & Three to Six Months & 230 & 57.5 \\
\hline & Less than three months & 118 & 29.5 \\
\hline \multirow{3}{*}{$\begin{array}{l}\text { Result of assessment/exam in the } \\
\text { online semester }\end{array}$} & 80 to $95 \%$ & 172 & 43.0 \\
\hline & 60 to $79 \%$ & 199 & 49.8 \\
\hline & less than $50 \%$ & 28 & 7.0 \\
\hline \multirow{2}{*}{ Preferred method of learning } & Blended & 333 & 83.3 \\
\hline & Online Learning & 67 & 16.8 \\
\hline \multirow{2}{*}{$\begin{array}{l}\text { Qualitative study should be } \\
\text { conducted on this topic }\end{array}$} & Yes & 181 & 45.3 \\
\hline & & 210 & 52.5 \\
\hline
\end{tabular}

Source: Author's data collection through online survey

Earlier studies on online learning show that it is easy and accessible which is not related with the finding of this study. The result of this study shows that students opposed the perception about online learning that it is easy and more accessible because lack of proper training and policies for online learning system. Majority of students preferred traditional education system because students considered the importance of non-verbal expression of teacher in class room learning. Students opposed the perception about online learning that it is easy and more accessible. Majority of students considered that blended learning is better than completely online learning. Quality of online educations has also been a serious concern of students. Students were not considering the online learning as effective education that builds insight and creativity because of low quality of online education (Watson, 2008).

the Coronavirus pandemic has compelled the educational institutions to adapt to the modern modes of pedagogy. Prior to these educational institutions were not willing to transform to online learning system swiftly. Classroom based educational system has been their priority. However, amidst coronavirus pandemic they had to accept modern technology for educational 
purposes. Owing to pandemic situation compelled Exposure to modern technology in the realm of education has wiped out many misconceptions and fears of educational institutions about online learning system. There has been a mushroom growth of e-classrooms from traditional classroom. In normal classroom the capacity of students in one classroom is limited. However, in online learning system hundreds of thousands can be taught at the same time and at any place in the world (Pandey, 2020). In this background, a number of universities around the world have adapted online learning system and have upgraded their online teaching infrastructure. However, there is a dire need to enhance the quality of education in online learning system. Overnight shift from traditional classrooms to e-classrooms has engendered various concerns regarding the quality of educations and pedagogical techniques which need to be tackled to make this system of learning more viable and result oriented (Crawford et al., 2020).

In table-2, results of the study showed that 29.7 percent students agreed while 13.5 percent students strongly agreed, 20.7 percent students stood neutral, 33.4 percent disagreed and 29.7 percent strongly disagreed with the initiative of online teaching by universities. Moreover, 29.5 percent students disagreed while 29.8 percent strongly disagreed on satisfaction with online learning. On the question of regular and actively attending online classes, 29.5 percent disagreed, 17.8 percent strongly disagreed. Much so, 26 percent disagreed, 16.3 percent strongly disagreed, 24.3 percent neutral, 26.8 percent agreed and 6.8 percent strongly agreed on the question on virtual existence of teacher and fellows in online classes. Regarding communication problems, 37 percent students agreed and 38.4percent students strongly agreed that they were facing problems to properly communicate with the class and teachers. Whether online education is more accessible or not 36 percent students disagreed and 21.51 strongly disagreed. Students are in the favour of blended learning system, and result showed 31.3 percent students agreed and 41.5 percent strongly agreed on it.

Question regarding online learning and development of creative thinking 31.5 percent disagreed and 20.3 percent strongly disagreed. Furthermore, 36.8 percent neutral, 25.8 percent disagreed, 13.3 percent strongly disagreed that online learning builds insight. Much so, 21.5 percent showed neutral response and 24.3 percent disagreed that online learning is based on research-oriented method of learning. In addition, 41.5 percent students considered online learning as independent learning method. Question on whether online learning ensures quality of education 29 percent students disagreed, whereas 18.5 percent strongly disagreed and 27 percent neutral. Moreover, 35.5 percent students disagreed and 30.8 percent strongly disagreed that online learning is good for undergraduate studies while 31 percent students disagreed for postgraduate studies through online class, 29 percent remained neutral. Moreover, 44.1 percent were facing concentration issues during online classes, 65.8 percent students strongly agreed and 23.9 percent students agreed that they were facing connectivity issues during online learning. Response on limitation of access to technology for online learning showed 46.3 percent agreed, 36.8 percent strongly agreed that there exists lack of access for online classes. Moving ahead, 46.3 percent students agreed, 34 percent strongly agreed that online learning system lacks students/teacher training. In addition, 46.8 percent agreed, 27.5 percent strongly agreed and 14.5 percent neutral that online learning system lack compatible teaching methodology. A large majority of student (83.9 percent) preferred the face-to-face classroom teaching method. Many students (47.8 percent) were motivated to share experience of their online classes qualitatively to better express their unique issues and challenges. Findings of this study indicate that hybrid learning is the future of educational system. There is a need to develop proper mechanism for online learning. 
Table-2: Attitudes of university students towards online learning

\begin{tabular}{|c|c|c|c|c|c|}
\hline \multirow[b]{2}{*}{ Questions } & \multicolumn{5}{|c|}{ Attitudes - n (\%) } \\
\hline & $\begin{array}{l}\text { Strongly } \\
\text { Disagree }\end{array}$ & Disagree & Neutral & Agree & $\begin{array}{l}\text { Strongly } \\
\text { Agree }\end{array}$ \\
\hline $\begin{array}{l}\text { In a pandemic situation, online learning is a } \\
\text { good initiative by educational institutes }\end{array}$ & $\begin{array}{c}57 \\
(14.3)\end{array}$ & $\begin{array}{c}85 \\
(21.3)\end{array}$ & $\begin{array}{c}86 \\
(21.3)\end{array}$ & $\begin{array}{l}119 \\
(29)\end{array}$ & $\begin{array}{c}53 \\
53 \\
(13.3)\end{array}$ \\
\hline $\begin{array}{l}\text { Students are attending online classes regularly } \\
\text { and actively }\end{array}$ & $\begin{array}{c}71 \\
(17.8)\end{array}$ & $\begin{array}{l}118 \\
(29.5)\end{array}$ & $\begin{array}{c}72 \\
(18.0)\end{array}$ & $\begin{array}{c}107 \\
(26.8)\end{array}$ & $\begin{array}{c}32 \\
(8.0)\end{array}$ \\
\hline $\begin{array}{l}\text { Students feel psychologically/mentally } \\
\text { satisfied with online learning }\end{array}$ & $\begin{array}{c}119 \\
(29.8)\end{array}$ & $\begin{array}{c}135 \\
(33.8) \\
\end{array}$ & $\begin{array}{c}77 \\
(19.3)\end{array}$ & $\begin{array}{c}48 \\
(12.0)\end{array}$ & $\begin{array}{c}21 \\
(5.3)\end{array}$ \\
\hline $\begin{array}{l}\text { Students feel good with the virtual existence of } \\
\text { your teacher and class fellows in online classes }\end{array}$ & $\begin{array}{c}65 \\
(16.3)\end{array}$ & $\begin{array}{c}104 \\
(26.0)\end{array}$ & $\begin{array}{c}97 \\
(24.3)\end{array}$ & $\begin{array}{c}107 \\
(26.8)\end{array}$ & $\begin{array}{c}27 \\
(6.8)\end{array}$ \\
\hline $\begin{array}{l}\text { Students put more mental effort to remain } \\
\text { focused during online classes }\end{array}$ & $\begin{array}{c}43 \\
(10.8)\end{array}$ & $\begin{array}{c}67 \\
(16.8)\end{array}$ & $\begin{array}{c}54 \\
(13.5)\end{array}$ & $\begin{array}{c}130 \\
(32.5)\end{array}$ & $\begin{array}{c}106 \\
(26.5)\end{array}$ \\
\hline $\begin{array}{l}\text { Students feel a communication problem during } \\
\text { online classes }\end{array}$ & $\begin{array}{c}16 \\
(4.0)\end{array}$ & $\begin{array}{c}32 \\
(8.0) \\
\end{array}$ & $\begin{array}{c}45 \\
(11.3)\end{array}$ & $\begin{array}{c}153 \\
(38.3)\end{array}$ & $\begin{array}{c}154 \\
(38.5)\end{array}$ \\
\hline $\begin{array}{l}\text { Expressions/body language affect learning in } \\
\text { online classes }\end{array}$ & $\begin{array}{c}26 \\
(6.5) \\
\end{array}$ & $\begin{array}{c}40 \\
(10.0) \\
\end{array}$ & $\begin{array}{c}61 \\
(15.3) \\
\end{array}$ & $\begin{array}{c}173 \\
(43.3) \\
\end{array}$ & $\begin{array}{c}100 \\
(25.0)\end{array}$ \\
\hline $\begin{array}{l}\text { Students feel difficulty to concentrate during } \\
\text { online classes }\end{array}$ & $\begin{array}{c}11 \\
(2.8)\end{array}$ & $\begin{array}{l}26 \\
(6.5)\end{array}$ & $\begin{array}{c}42 \\
(10.5)\end{array}$ & $\begin{array}{c}144 \\
(36.0)\end{array}$ & $\begin{array}{c}177 \\
(44.3)\end{array}$ \\
\hline $\begin{array}{l}\text { Students think online learning is easy and more } \\
\text { accessible }\end{array}$ & $\begin{array}{c}85 \\
(21.3) \\
\end{array}$ & $\begin{array}{c}144 \\
(36.0) \\
\end{array}$ & $\begin{array}{c}72 \\
(18.0) \\
\end{array}$ & $\begin{array}{c}75 \\
(18.8) \\
\end{array}$ & $\begin{array}{c}24 \\
(6.0) \\
\end{array}$ \\
\hline Blended learning is better than online & $\begin{array}{c}23 \\
(5.8)\end{array}$ & $\begin{array}{c}34 \\
(8.5)\end{array}$ & $\begin{array}{c}49 \\
(12.3)\end{array}$ & $\begin{array}{c}125 \\
(31.3)\end{array}$ & $\begin{array}{c}166 \\
(41.5)\end{array}$ \\
\hline $\begin{array}{l}\text { Online learning helps to develop creative } \\
\text { thinking }\end{array}$ & $\begin{array}{c}81 \\
(20.3)\end{array}$ & $\begin{array}{c}126 \\
(31.5)\end{array}$ & $\begin{array}{c}81 \\
(20.3)\end{array}$ & $\begin{array}{c}79 \\
(19.8)\end{array}$ & $\begin{array}{c}30 \\
(7.5)\end{array}$ \\
\hline $\begin{array}{l}\text { Do you agree that online learning builds } \\
\text { insight? }\end{array}$ & $\begin{array}{c}53 \\
(13.3) \\
\end{array}$ & $\begin{array}{l}103 \\
(25.8)\end{array}$ & $\begin{array}{c}147 \\
(36.8)\end{array}$ & $\begin{array}{c}72 \\
(18.0) \\
\end{array}$ & $\begin{array}{c}22 \\
(5.5) \\
\end{array}$ \\
\hline $\begin{array}{l}\text { Online learning is based on conceptual clarity } \\
\text { and research-oriented method }\end{array}$ & $\begin{array}{c}61 \\
(15.3)\end{array}$ & $\begin{array}{c}97 \\
(24.3)\end{array}$ & $\begin{array}{c}86 \\
(21.5)\end{array}$ & $\begin{array}{c}118 \\
(29.5)\end{array}$ & $\begin{array}{c}36 \\
(9.0)\end{array}$ \\
\hline $\begin{array}{l}\text { Online learning system demands more focus } \\
\text { and attention of a learner }\end{array}$ & $\begin{array}{c}30 \\
(7.5)\end{array}$ & $\begin{array}{c}21 \\
(5.3)\end{array}$ & $\begin{array}{c}44 \\
(11.0)\end{array}$ & $\begin{array}{c}171 \\
(42.8) \\
\end{array}$ & $\begin{array}{c}132 \\
(33.0)\end{array}$ \\
\hline $\begin{array}{l}\text { Online learning is the independent learning } \\
\text { method }\end{array}$ & $\begin{array}{c}23 \\
(5.8)\end{array}$ & $\begin{array}{c}61 \\
(15.3)\end{array}$ & $\begin{array}{c}89 \\
(22.3)\end{array}$ & $\begin{array}{c}166 \\
(41.5)\end{array}$ & $\begin{array}{c}58 \\
(14.5)\end{array}$ \\
\hline $\begin{array}{l}\text { Online learning system ensures the quality of } \\
\text { education }\end{array}$ & $\begin{array}{c}74 \\
(18.5) \\
\end{array}$ & $\begin{array}{c}116 \\
(29.0)\end{array}$ & $\begin{array}{c}108 \\
(27.0)\end{array}$ & $\begin{array}{c}79 \\
(19.8)\end{array}$ & $\begin{array}{c}20 \\
(5.0)\end{array}$ \\
\hline $\begin{array}{l}\text { The value of an online degree is as same as the } \\
\text { regular/ traditional degree }\end{array}$ & $\begin{array}{c}121 \\
(30.3)\end{array}$ & $\begin{array}{c}135 \\
(33.8)\end{array}$ & $\begin{array}{c}56 \\
(14.0) \\
\end{array}$ & $\begin{array}{c}65 \\
(16.3)\end{array}$ & $\begin{array}{c}21 \\
(5.3)\end{array}$ \\
\hline $\begin{array}{l}\text { Online learning is good for all areas of study at } \\
\text { the undergraduate level }\end{array}$ & $\begin{array}{c}123 \\
(30.8)\end{array}$ & $\begin{array}{c}142 \\
(35.5)\end{array}$ & $\begin{array}{c}65 \\
(16.3)\end{array}$ & $\begin{array}{c}50 \\
(12.5)\end{array}$ & $\begin{array}{l}18 \\
(4.5)\end{array}$ \\
\hline $\begin{array}{l}\text { Online learning is good only for postgraduate } \\
\text { level }\end{array}$ & $\begin{array}{c}68 \\
(17.0) \\
\end{array}$ & $\begin{array}{c}124 \\
(31.0)\end{array}$ & $\begin{array}{c}116 \\
(29.0)\end{array}$ & $\begin{array}{c}70 \\
(17.5) \\
\end{array}$ & $\begin{array}{c}19 \\
(4.8)\end{array}$ \\
\hline $\begin{array}{l}\text { Assessment in an online learning system is } \\
\text { more transparent }\end{array}$ & $\begin{array}{c}72 \\
(18.0)\end{array}$ & $\begin{array}{c}93 \\
(23.3)\end{array}$ & $\begin{array}{c}126 \\
(31.5)\end{array}$ & $\begin{array}{c}86 \\
(21.5)\end{array}$ & $\begin{array}{c}21 \\
(5.3)\end{array}$ \\
\hline $\begin{array}{l}\text { Students face internet problem during online } \\
\text { classes }\end{array}$ & $\begin{array}{c}7 \\
(1.8) \\
\end{array}$ & $\begin{array}{c}12 \\
(3.0) \\
\end{array}$ & $\begin{array}{c}21 \\
(5.3) \\
\end{array}$ & $\begin{array}{c}96 \\
(24.0) \\
\end{array}$ & $\begin{array}{c}262 \\
(65.5)\end{array}$ \\
\hline $\begin{array}{l}\text { Students have limited access to technology for } \\
\text { online learning }\end{array}$ & $5(1.3)$ & $\begin{array}{c}27 \\
(6.8)\end{array}$ & $\begin{array}{c}34 \\
(8.5)\end{array}$ & $\begin{array}{c}185 \\
(46.3)\end{array}$ & $\begin{array}{c}147 \\
(36.8)\end{array}$ \\
\hline $\begin{array}{l}\text { Online learning system lacks students/teachers } \\
\text { training for effective education }\end{array}$ & $\begin{array}{c}13 \\
(3.3)\end{array}$ & $\begin{array}{c}23 \\
(5.8)\end{array}$ & $\begin{array}{c}43 \\
(10.8)\end{array}$ & $\begin{array}{c}185 \\
(46.3)\end{array}$ & $\begin{array}{c}136 \\
(34.0)\end{array}$ \\
\hline $\begin{array}{l}\text { Online learning system lacks compatible } \\
\text { teaching methodology }\end{array}$ & $\begin{array}{c}11 \\
(2.8)\end{array}$ & $\begin{array}{c}32 \\
(8.0)\end{array}$ & $\begin{array}{c}58 \\
(14.5)\end{array}$ & $\begin{array}{c}187 \\
(46.8)\end{array}$ & $\begin{array}{c}110 \\
(27.5)\end{array}$ \\
\hline
\end{tabular}




\section{Conclusion}

This study established that although digital technology is popular in Pakistan, yet its utilization in educational domain is not completely actualized. Students are more tilted towards traditional system of education in classrooms than e-learning. Various issues are involved in nervousness and shock in response to this novel system amidst lockdown. This study spotlights issues involved in expectations of learners and new learning environment provided by online system. This study also conduced that teaching faculty needs to be trained regarding use of online learning system and development of lesson plan with low level of cognitive load coupled with efficient online system to make it easy for the students. This study highlighted the Issues involved in online learning are caused by its hasty launch; however, such problems can be vanished with more investment in this sector and enhancement of online teaching infrastructure. In this exigency there is a need for effective measures at the part of administrations and faculty members for a better and effective learning of students during lockdown situation.

\subsection{Recommendations}

Non- random selection of samples puts limitations on generality of this study. Future researches use random selection techniques, therefore such sample obtained through non-random selection is a bar on generalization of results of this study. As results are based on students only from Punjab province, further studies from other provinces may help in understanding issues of these provinces.

\subsection{Implications of the study}

This study outlines the existing issues in adoption of online learning system. It can provide a guideline for making online learning system more robust and adaptable. This study will provide the basic facts about online learning in pandemic situation. The finding of the study can be helpful to explore this topic for qualitative research.

\section{References}

Adams, N. E. (2015). Bloom's taxonomy of cognitive learning objectives. Journal of the Medical Library Association: JMLA, 103(3), 152-153. https://dx.doi.org/10.3163\%2F1536-5050.103.3.010

Adnan, M., \& Anwar, K. (2020). Online learning amid the COVID-19 pandemic: students' perspectives. Online Submission, 2(1), 45-51. https://doi.org/10.33902/JPSP. $\underline{2020261309}$

Allen, I. E., \& Seaman, J. (2008). Staying the course: online education in the United States, 2008: ERIC. https://files.eric.ed.gov/fulltext/ED529698.pdf

Aslam. T., Rizvi, S. M. A. S., \& Ahmad, J. (2020). Virtual learning strategies during Covid19: a case study of the University of Lahore, Pakistan. Liberal Arts and Social Sciences International Journal (LASSIJ), 4(2), 427-440. https://doi.org/10.47264/idea.lassij/4.2.33

Bulman, G., \& Fairlie, R. W. (2016). Technology and education: computers, software, and the internet. Handbook of the Economics of Education 5, 239-280. https://doi.org/10.1016/B978-0-444-63459-7.00005-1 
Burgess, S., \& Sievertsen, H. H. (2020). Schools, skills, and learning: the impact of COVID19 on education. VoxEu. https://voxeu.org/article/impact-covid-19-education

Cojocariu, V. M., \& Boghian, I. (2014). Teaching the relevance of game-based learning to preschool and primary teachers. Procedia-Social and Behavioural Sciences, 142, 640-646. https://doi.org/10.1016/j.sbspro.2014.07.679

Crawford, J., Butler-Henderson, K., Rudolph, J., Malkawi, B., Glowatz, M., Burton, R., .. . Lam, S. (2020). COVID-19: 20 countries' higher education intra-period digital pedagogy responses. Journal of Applied Learning \& Teaching, 3(1), 1-20. http://dx.doi.org/10.37074/jalt.2020.3.1.7

Dhawan, S. (2020). Online learning: A panacea in the time of COVID-19 crisis. Journal of Educational Technology Systems, 49(1), 5-22. https://doi.org/10.1177/0047239520934018

Flack, C. B., Walker, L., Bickerstaff, A., \& Margetts, C. (2020, July). Socioeconomic disparities in Australian schooling during the COVID-19 pandemic. Pivot Professional Learning. 1-36. https://pivotpl.com/wpcontent/uploads/2020/07/Pivot_Socioeconomic-disparities-in-Australian-schoolingduring-COVID-19 1 July2020.pdf

Hoq, M. Z. (2020). E-learning during the period of pandemic (COVID-19) in the Kingdom of Saudi Arabia: an empirical study. American Journal of Educational Research, 8(7), 457-464. http://article.scieducationalresearch.com/pdf/education-8-7-2.pdf

James, R., Bexley, E., Anderson, A., Devlin, M., Garnett, R., Marginson, S., \& Maxwell, L. (2008). Participation and equity: a review of the participation in higher education of people from low socioeconomic backgrounds and Indigenous people (Doctoral dissertation, University of Melbourne. Centre for the Study of Higher Education). http://hdl.voced.edu.au/10707/31488.

Kumar, P. (2020). Reference based study on impact of Covid-19 on education systems. https://core.ac.uk/download/pdf/327105065.pdf

Maddux, C., Sprague, D., Ferdig, R., \& Albion, P. (2007). Online education: issues and research questions. Journal of Technology and Teacher Education, 15(2), 157-166. https://www.learntechlib.org/primary/p/24317/.

McBrien, J. L., Cheng, R., \& Jones, P. (2009). Virtual spaces: employing a synchronous online classroom to facilitate student engagement in online learning. International Review of Research in Open and Distributed Learning, 10(3), 1-17. https://doi.org/10.19173/irrodl.v10i3.605

McDonnell, J. W. (2019). Maine's workforce challenges in an age of artificial intelligence. Maine Policy Review, 28(1), 11-16. https://digitalcommons.library.umaine.edu/cgi/viewcontent.cgi?article=1825\&conte $\underline{\mathrm{xt}=\mathrm{mpr}}$

Nguyen, T. (2015). The effectiveness of online learning: beyond no significant difference and future horizons. MERLOT Journal of Online Learning and Teaching, 11(2), 309-319. https://jolt.merlot.org/Vol11no2/Nguyen_0615.pdf

$\mathrm{Ni}, \mathrm{A} . \mathrm{Y}$. (2013). Comparing the effectiveness of classroom and online learning: teaching research methods. Journal of Public Affairs Education, 19(2), 199-215. https://doi.org/10.1080/15236803.2013.12001730

Nicola, M., Alsafi, Z., Sohrabi, C., Kerwan, A., Al-Jabir, A., Iosifidis, C., Agha, R. (2020). The socio-economic implications of the coronavirus pandemic (COVID-19): a review. International Journal of Surgery 83, 189-191. https://doi.org/10.1016/j.ijsu.2020.04.018 
Pace, C., Pettit, S. K., \& Barker, K. S. (2020). Best practices in middle level quaranteaching: strategies, tips, and resources amidst COVID-19. Becoming: Journal of the Georgia Association for Middle Level Education, 31(1), 1-13. https://doi.org/10.20429/becoming.2020.310102

Pandey, D. K. (2020). Covid-19 lockdown: an opportunity to explore new frontiers for onlinetraining. Electronic Journal of Social and Strategic Studies 1(1), 53-66. https://doi.org/10.47362/EJSSS.2020.1104

Salam, S., Jianqiu, Z., Pathan, Z. H., \& Lei, W. (2017, December). Strategic barriers in the effective integration of ICT in the public schools of Pakistan. In Proceedings of the 2017 International Conference on Computer Science and Artificial Intelligence, 169172. https://doi.org/10.1145/3168390.3168422

Singh, V., \& Thurman, A. (2019). How many ways can we define online learning? a systematic literature review of definitions of online learning (1988-2018). American Journal of Distance Education, 33(4), 289-306. https://doi.org/10.1080/08923647.2019.1663082

Stage, H. B., Shingleton, J., Ghosh, S., Scarabel, F., Pellis, L., \& Finnie, T. (2020). Shut and re-open: the role of schools in the spread of COVID-19 in Europe. Medrxiv.1-28. https://doi.org/10.1101/2020.06.24.20139634

Viner, R. M., Russell, S. J., Croker, H., Packer, J., Ward, J., Stansfield, C., ... \& Booy, R. (2020). School closure and management practices during coronavirus outbreaks including COVID-19: a rapid systematic review. The Lancet Child \& Adolescent Health, 4(5), 397-404. https://doi.org/10.1016/S2352-4642(20)30095-X

Watson, J. (2008). Blended Learning: The convergence of online and face-to-face education: promising practices in online learning. North American Council for Online Learning. https://eric.ed.gov/?id=ED509636

Zeglen, E., \& Rosendale, J. (2018). Increasing online information retention: analyzing the effects. Journal of Open, Flexible, and Distance Learning, 22(1), 22-33. https://www.learntechlib.org/p/184660/

Zhang, H., Penninger, J. M., Li, Y., Zhong, N., \& Slutsky, A. S. (2020). Angiotensinconverting enzyme 2 (ACE2) as a SARS-CoV-2 receptor: molecular mechanisms and potential therapeutic target. Intensive Care Medicine, 46(4), 586-590. https://doi.org/10.1007/s00134-020-05985-9 


\section{Appendix-A}

Section-1: Demographic Profile of the Respondent

1. Name: (Optional)

2. Age: 1-17-21 years 2- 22 year and above

3. Gender: Female ___ Male

4. Felid of Study: Sciences___ Social Sciences___ Art and Humanities

5. Level of study: Undergraduate____ Post graduate

6. Previous Semester GPA: 3.00 to above___ 2.50 to $3.00 \_2.00$ to 2.50

7. University in which studying: Public___ Private__________ gemi government

8. Attending Online Classes through: Zoom___ WhatsApp ___Recorded Lecture

9. Attending online classes Since: Six months and above ___ Three to Six Months Less than three months

10. Result of assessment/exam in the online semester: 80 to $95 \%$ 60 to $79 \%$ than $50 \%$

11. Preferred method of learning: Blended online Learning

12. Qualitative study should be conducted on this topic: Yes No

Section-2: Rate the following statement from scale a to e.
Note: a. Strongly Disagree
b. Disagree
c. Neutral
d. Agree
e. Strongly Agree

1. In a pandemic situation, online learning is a good initiative by educational institutes

2. Students are attending online classes regularly and actively

3. Students feel psychologically/mentally satisfied with online learning

4. Students feel good with the virtual existence of your teacher and class fellows in online classes

5. Students put more mental effort to remain focused during online classes

6. Students feel a communication problem during online classes

7. Expressions/body language affect learning in online classes

8. Students feel difficulty to concentrate during online classes

9. Students think online learning is easy and more accessible

10. Blended learning is better than online

11. Online learning helps to develop creative thinking

12. Do you agree that online learning builds insight?

13. Online learning is based on conceptual clarity and research-oriented method

14. Online learning system demands more focus and attention of a learner

15. Online learning is the independent learning method

16. Online learning system ensures the quality of education

17. The value of an online degree is as same as the regular/ traditional degree

18. Online learning is good for all areas of study at the undergraduate level

19. Online learning is good only for postgraduate level

20. Assessment in an online learning system is more transparent

21. Students face internet problem during online classes

22. Students have limited access to technology for online learning

23. Online learning system lacks students/teachers training for effective education

24. Online learning system lacks compatible teaching methodology 